\title{
Cariology education for undergraduate Brazilian dental students
}

\author{
Ensino da cariologia para estudantes de graduação em odontologia no Brasil
}

\author{
Daiana Back GOUVEA' \\ (D) ORCID iD 0000-0003-1180-9326 \\ Sonia GROISMAN² \\ (iD) ORCID iD 0000-0003-1153-3841 \\ Marcelo José Strazzeri BÖNECKER ${ }^{3}$ \\ (iD) ORCID ID 0000-0001-9786-6473 \\ Fabio SAMPAIO 4 \\ (i) ORCID iD 0000-0003-2870-5742 \\ Saul Martins PAIVA ${ }^{5}$ \\ (iD) ORCID iD 0000-0002-3968-1638 \\ Léo KRIGER ${ }^{6}$ \\ (i) ORCID iD 0000-0002-9932-531x \\ Andreas SCHULTE? \\ (iD) ORCID iD 0000-0002-5533-6578 \\ Jonas Almeida RODRIGUES \\ (iD) ORCID iD 0000-0001-8887-2329
}

\begin{abstract}
This study sought to provide an overview of current cariology education for undergraduate Brazilian dental students. Data collection was via a Portuguese version of a 12-item questionnaire (Schulte et al., 2011) that was sent to all Brazilian dental schools $(n=219)$. The response rate was $57.0 \%(n=125)$. Of the schools that returned the questionnaire, $84.8 \%$ supported the development of a Brazilian cariology curriculum. The units responsible for teaching cariology were predominantly operative dentistry (49.6\%), pediatric dentistry (49.6\%), dental public health (44.8\%), and cariology (32\%). Theoretical teaching of cariology (74.4\%) and pre-clinical exercises (63.2\%) were cited to occur mainly during the second year of the course, while clinical activities were placed in the third (71.2\%) and fourth (64.8\%) years. Among respondents, $76.8 \%$ of the schools included dental erosion and $86.4 \%$ included defects of dental hard tissues, such as abrasion, in teaching cariology. This survey was able to determine the panorama of cariology education in Brazil and to detect some differences among Brazilian geographic areas. The promotion of a workshop to discuss the topics that should be taught to undergraduate dental students and the development of a Brazilian core curriculum in cariology would be likely to reduce the differences in teaching cariology in Brazil.
\end{abstract}

Indexing terms: Curriculum. Dental caries. Teaching.

\section{RESUMO}

Este estudo teve como objetivo apresentar um panorama do ensino de cariologia nos cursos de graduação em Odontologia no Brasil. A coleta de dados foi realizada por meio de uma versão em Português Brasileiro de um questionário de 12 itens (Schulte et al., 2011) que foi enviado a todas as faculdades de Odontologia brasileiras $(n=219)$. A taxa de resposta foi de $57,0 \%(n=125)$. Dentre as faculdades que responderam o questionário, $84,8 \%$ apoiam o desenvolvimento de um currículo brasileiro de cariologia. As disciplinas responsáveis por lecionar os conteúdos de cariologia são principalmente dentística (49,6\%), odontopediatria (49,6\%), saúde bucal coletiva (44,8\%), e cariologia (32\%). O ensino teórico de cariologia $(74,4 \%)$ e os exercícios de pré-clínica $(63,2 \%)$ são abordados principalmente durante o segundo ano do curso, enquanto as atividades clínicas ocorrem, em geral, no terceiro $(71,2 \%)$ e quarto $(64,8 \%)$ anos. Dentre os respondentes, $76,8 \%$ das faculdades incluem erosão dentária e $86,4 \%$ incluem defeitos dos tecidos dentários duros, como abrasão, no ensino da cariologia. Essa pesquisa foi capaz de determinar o panorama do ensino da cariologia no Brasil e detectar algumas diferenças de currículo entre as regiões do país. A promoção de um workshop para discutir os assuntos que devem ser ministrados aos estudantes de graduação em Odontologia e para desenvolver um currículo brasileiro de cariologia seria válida para reduzir as diferenças no ensino de cariologia no Brasil.

Termos de indexação: Currículo. Cárie dentária. Ensino.

\footnotetext{
${ }^{1}$ Universidade Federal do Rio Grande do Sul, Faculdade de Odontologia. Rua Ramiro Barcelos, 2492, Porto Alegre, RS, Brasil. Correspondência para / Correspondence to: DB GOUVEA. Email: <daianabgouvea@gmail.com>.

${ }^{2}$ Universidade Federal do Rio de Janeiro, Faculdade de Odontologia, Departamento de Odontologia Social e Preventiva. Rio de Janeiro, RJ, Brasil.

${ }^{3}$ Universidade de São Paulo, Faculdade de Odontologia, Departamento de Odontopediatria. São Paulo, SP, Brasil.

${ }^{4}$ Universidade Federal da Paraíba, Faculdade de Odontologia, Departamento de Clínica e Odontologia Social. João Pessoa, PB, Brasil.

${ }^{5}$ Universidade Federal de Minas Gerais, Faculdade de Odontologia, Departamento de Odontopediatria e Ortodontia.

${ }^{6}$ Pontifícia Universidade Católica do Paraná. Curitiba, PR, Brasil.

${ }^{7}$ Private Universität Witten. Witten, Renânia, Alemanha.

${ }^{8}$ Universidade Federal do Rio Grande do Sul, Faculdade de Odontologia, Departamento de Cirurgia e Ortopedia. Porto Alegre, RS, Brasil.

$\mathbf{\nabla} \mathbf{\nabla} \boldsymbol{\nabla}$

Como citar este artigo / How to cite this article

Gouvea DB, Groisman S, Bönecker MJS, Sampaio F, Paiva SM, Kriger L, et al. Cariology education for undergraduate Brazilian dental students. RGO, Rev Gaúch Odontol. 2018;66(3):239-244. http://dx.doi.org/10.1590/1981-863720180003000073428
} 


\section{INTRODUCTION}

Dental caries has shown a marked decrease in both incidence and prevalence in the Brazilian population [1]. An epidemiological survey performed in 2010 showed that Brazil now presents low caries prevalence in a sample of 12 year old subjects according to the World Health Organization (WHO) classification [2]. The disease, however, has a polarized profile in the country since the prevalence is still high among deprived groups [1].

For many years, the dentist profile has been described as traditional and mainly focused on technical aspects of oral health care. However, there is still the need for professionals engaged in oral health promotion to be able to diagnose dental caries and to consider the interaction among biological, environmental, and socioeconomic aspects [3].

Oral health teaching has been fragmented, and because of this, the adequate synthesis of the knowledge is not observed [4]. This model reflects on the biological dentist formation that does not consider social determinants to establish clinical management. This panorama supports the elaboration of a curriculum that provides knowledge integration, early diagnosis, and treatment in a translational perspective.

In Europe, a number of dental disciplines have published guidelines specifying the items in their disciplines to be included in the agenda of dental teaching [5-9]. Surprisingly, up to 2010, nothing about cariology education had been written. To overcome this, the European Organization for Caries Research (ORCA) and the Association for Dental Education in Europe (ADEE) conducted a survey on cariology education in European dental colleges to obtain data that should serve as basis for the elaboration of a European core curriculum in cariology [10]. Following this, in 2010, the first consensus workshop for the development of a cariology core curriculum was held in Berlin. During this event, the participants discussed and agreed on the most relevant items regarding teaching cariology [11].

In Latin America, efforts have been made to investigate the state of teaching cariology and the availability of a cariology curriculum. A survey was conducted between 2009 and 2011 among Spanishspeaking Latin American dental schools from 16 countries, which included questions about curriculum, diagnosis, treatment, and perceptions, all with regard to cariology [12]. After this project, regional workshops to discuss aspects of teaching cariology were organized in Colombia using the document of the "European Cariology Core Curriculum" as basis for the discussions. The outcome of these workshops was used to create the Colombian cariology curriculum. The final document was agreed upon with the aid of a structured consensus process in which 23 Colombian dental schools took part [13].

Recently, in Brazil, some initiatives to assess how cariology has been taught were undertaken. Methods involving analysis of curriculum courses [14] and the conceptualization of dental caries by students [15] were used to initially evaluate the insertion of cariology content. However, data on teaching cariology in different geographic areas in the country are still missing. Therefore, the aim of this survey was to provide an overview of current cariology education for undergraduate Brazilian dental students similar to the survey performed by ORCA and ADEE in Europe.

\section{METHODS}

After approval by the Ethics Committee of the Federal University of Rio Grande do Sul (Presentation Certificate of Appreciation for Ethics number 42725715.7.0000.5347), a 12-item Brazilian Portuguese language questionnaire was developed based on the translation of the instrument used by ORCA and ADEE to perform the investigation [10]. The translation to Brazilian Portuguese was realized according to the method "translate-translate back" in three steps:

1. Translation of the European document, which was published in the English language into the Brazilian Portuguese language by two translators;

2. The Portuguese version of the document was assessed by a third translator who translated the Brazilian version back into English; and

3. The first two translators compared the original European version in English with the English language version provided by the third translator and adjusted when necessary.

After this, the questionnaire was sent to 73 dental schools for a preliminary survey [3]. By this preliminary investigation, some difficulties in filling out the questionnaire were detected and small changes were made to favor the understanding of the questions. The revised version of the questionnaire and the online informed consent were developed using the virtual tool "Google Forms." The questionnaire and the informed 
consent were available online and a web link was sent by email to the coordinators of all 219 Brazilian dental schools (total of registered schools up to 2014), a well as to the 73 that answered the preliminary survey using an account created specifically for this purpose. Data were analyzed descriptively and frequencies of answers are presented.

\section{RESULTS}

A total of 125 dental schools responded the questionnaire (response rate of $57.0 \%$ ). Of these schools, $74.4 \%$ were private schools and $27.2 \%$ were public. The national response rate was 57.0\% (125 dental schools). Analyzing all five Brazilian geographic regions individually, the responses rates were $66.6 \%$ (south), $55.5 \%$ (southeast), $68.4 \%$ (midwest), $60.0 \%$ (northeast), and $31.8 \%$ (north). Concerning public (free) and private institutions, a higher response rate $(66.6 \%)$ was observed for public schools than for private schools (55.3\%). Of the 125 schools that returned the questionnaire, $84.8 \%$ supported the development of a Brazilian cariology curriculum (table 1).

Table 1. Response rate and supporting of a Brazilian Cariology curriculum.

\begin{tabular}{lcc}
\hline & \multicolumn{2}{c}{ Dental schools } \\
\cline { 2 - 3 } & $\begin{array}{c}\text { Response rate } \\
\mathrm{n}(\%)\end{array}$ & $\begin{array}{c}\text { Supporting of a } \\
\text { national curriculum } \\
\mathrm{n}(\%)\end{array}$ \\
\hline Brazil & $125(57.0)$ & $106(84.8)$ \\
South & $26(66.6)$ & $22(84.6)$ \\
Southeast & $52(55.5)$ & $45(86.5)$ \\
Midwest & $13(68.4)$ & $7(53.8)$ \\
Northeast & $27(60.0)$ & $25(92.6)$ \\
North & $7(31.8)$ & $7(100)$ \\
Public & $34(66.6)$ & $28(82.3)$ \\
Private & $93(55.3)$ & $75(80.6)$ \\
\hline
\end{tabular}

Regarding the units responsible for teaching cariology, $32.0 \%$ of the schools had a specific subject named cariology, while other units included operative dentistry $(49.6 \%)$, pediatric dentistry $(49.6 \%)$, and dental public health (44.8\%) (table 2). The subject content was available in written form in $76.8 \%$ of the institutions, and the expressions cariology or dental caries were present in the titles of the classes or units in $92.8 \%$ of the schools.

Considering the type of education in cariology, the theoretical teaching and the pre-clinical exercises using extracted teeth or phantoms occur predominantly in the second year of the course in dental education. With regard to clinical education, most of the schools placed these activities in the third and fourth years of the course in dental education (table 3 ).

Table 2. Disciplines responsible for teaching Cariology in Brazil

\begin{tabular}{ccccccc}
\hline Discipline & $\begin{array}{c}\text { Brazil } \\
\mathrm{n}(\%)\end{array}$ & $\begin{array}{c}\text { South } \\
\mathrm{n}(\%)\end{array}$ & $\begin{array}{c}\text { Southeast } \\
\mathrm{n}(\%)\end{array}$ & $\begin{array}{c}\text { Midwest } \\
\mathrm{n}(\%)\end{array}$ & $\begin{array}{c}\text { Northeast } \\
\mathrm{n}(\%)\end{array}$ & $\begin{array}{c}\text { North } \\
\mathrm{n}(\%)\end{array}$ \\
\hline Cariology & 40 & $7(5.6)$ & 20 & 1 & 10 & 2 \\
$(32.0)$ & & $(38.4)$ & $(7.7)$ & $(37.0)$ & $(28.5)$ \\
Operative/ & 62 & 9 & 31 & 7 & 12 & 3 \\
Restorative & $(49.6)$ & $(34.6)$ & $(59.6)$ & $(53.8)$ & $(44.4)$ & $(42.8)$ \\
Dentistry & & & & & & \\
Pediatric & 62 & 14 & 21 & 8 & 16 & 3 \\
Dentistry & $(49.6)$ & $(53.8)$ & $(40.3)$ & $(61.5)$ & $(59.2)$ & $(42.8)$ \\
Public & 56 & 15 & 22 & 6 & 9 & 4 \\
Health & $(44.8)$ & $(57.7)$ & $(42.3)$ & $(46.1)$ & $(33.3)$ & $(57.1)$ \\
\hline
\end{tabular}

Table 3. Type of Cariology education during the years of course.

\begin{tabular}{cccc}
\hline Year & \multicolumn{3}{c}{ Cariology Education } \\
\hline & $\begin{array}{c}\text { Theoretical } \\
\mathrm{n}(\%)\end{array}$ & $\begin{array}{c}\text { Pre-clinical } \\
\mathrm{n}(\%)\end{array}$ & $\begin{array}{c}\text { Clinical } \\
\mathrm{n}(\%)\end{array}$ \\
\hline $1^{\text {st }}$ & $58(46.4)$ & $20(16.0)$ & $4(3.2)$ \\
$2^{\text {nd }}$ & $93(74.4)$ & $79(63.2)$ & $49(39.2)$ \\
$3^{\text {rd }}$ & $67(53.6)$ & $42(33.6)$ & $89(71.2)$ \\
$4^{\text {th }}$ & $53(42.4)$ & $15(12.0)$ & $81(64.8)$ \\
$5^{\text {th }}$ & $16(12.8)$ & $5(4.0)$ & $52(41.6)$ \\
\hline
\end{tabular}

Concerning the inclusion of content that is important for differential diagnosis of dental caries in the cariology curriculum, $76.8 \%$ of the schools reported including dental erosion and $86.4 \%$ included defects of dental hard tissues like abrasion.

Moreover, the questionnaire included a question that presented 29 items related to cariology and dental erosion. The respondents should have selected the items with most importance to the cariology curriculum. Out of these 29 items, 12 showed rates of agreement higher than $90 \%$ (table 4). 
Table 4. Contents judged important to be included in the Cariology curriculum.

\begin{tabular}{|c|c|}
\hline Contents & $\begin{array}{c}\text { Respondents agreement } \\
\mathrm{n}(\%)\end{array}$ \\
\hline Etiology of dental caries & $123(98.4)$ \\
\hline $\begin{array}{l}\text { Role of fluoride in caries } \\
\text { prevention }\end{array}$ & $120(96.0)$ \\
\hline $\begin{array}{l}\text { Clinical detection of carious } \\
\text { lesions }\end{array}$ & $120(96.0)$ \\
\hline $\begin{array}{l}\text { Clinical and histological } \\
\text { appearance of dental caries } \\
\text { lesions }\end{array}$ & $119(95.2)$ \\
\hline Diet & $119(95.2)$ \\
\hline $\begin{array}{l}\text { Remineralization of dental } \\
\text { hard tissues affected by } \\
\text { caries }\end{array}$ & $119(95.2)$ \\
\hline Caries risk assessment & $117(93.6)$ \\
\hline $\begin{array}{l}\text { Caries prevention in patients } \\
\text { (monitoring) }\end{array}$ & $117(93.6)$ \\
\hline Biofilm & $117(93.6)$ \\
\hline $\begin{array}{l}\text { Chemical and mechanical } \\
\text { biofilm removal }\end{array}$ & $117(93.6)$ \\
\hline Microbiology & $115(92.0)$ \\
\hline $\begin{array}{l}\text { Radiological detection of } \\
\text { carious lesions }\end{array}$ & $114(91.2)$ \\
\hline $\begin{array}{l}\text { Auxiliary for detection of } \\
\text { carious lesions }\end{array}$ & $112(89.6)$ \\
\hline Saliva and salivary glands & $111(88.8)$ \\
\hline Caries Selective removal & $111(88.8)$ \\
\hline $\begin{array}{l}\text { Descriptive and analytical } \\
\text { epidemiology of dental } \\
\text { caries }\end{array}$ & $108(86.4)$ \\
\hline $\begin{array}{l}\text { Caries prevention in } \\
\text { populations }\end{array}$ & $108(86.4)$ \\
\hline $\begin{array}{l}\text { Professional and individual } \\
\text { biofilm removal }\end{array}$ & $106(84.8)$ \\
\hline $\begin{array}{l}\text { Treatment based on caries } \\
\text { activity }\end{array}$ & $98(78.5)$ \\
\hline $\begin{array}{l}\text { Atraumatic restorative } \\
\text { treatment }\end{array}$ & $92(73.6)$ \\
\hline Etiology of dental erosion & $91(72.8)$ \\
\hline Sealing of carious lesion & $90(72.0)$ \\
\hline Caries Total removal & $88(70.4)$ \\
\hline $\begin{array}{l}\text { Role of fluoride in dental } \\
\text { erosion prevention }\end{array}$ & $88(70.4)$ \\
\hline $\begin{array}{l}\text { Clinical and histological } \\
\text { appearance of dental } \\
\text { erosion }\end{array}$ & $85(68.0)$ \\
\hline Minimal intervention & $85(68.0)$ \\
\hline $\begin{array}{l}\text { Anatomy and histology of } \\
\text { dental tissues }\end{array}$ & $80(64.0)$ \\
\hline $\begin{array}{l}\text { Descriptive and analytical } \\
\text { epidemiology of dental } \\
\text { erosion }\end{array}$ & $72(57.6)$ \\
\hline Behavioral sciences & $64(51.2)$ \\
\hline
\end{tabular}

\section{DISCUSSION}

The present study aimed to investigate details of teaching cariology in Brazil. The observed response rate was $57.0 \%$. Similar studies performed in Spanish-speaking countries of Latin America and Europe yielded response rates varying between $60.0 \%$ [12] and $72.0 \%$ [10].

The results of the present study revealed that several units are responsible for teaching cariology. Besides cariology, the most cited units were operative dentistry, pediatric dentistry, and public health. This result corroborates to the outcomes observed in Europe and Spanish-speaking countries of Latin America. The percentage of dental schools in Brazil that provide a specific discipline of cariology seems to be higher than reported in Europe and other countries of Latin America $[10,12]$. What really matters is that cariology content is being taught to students, not necessarily under a specific named cariology subject. Besides that, it would be of utmost importance that specific disciplines, such as operative/restorative dentistry, also focus on aspects related to caries management and control of the disease and not only on restorative materials and interventional treatments following the actual status of caries process.

With regard to the beginning of cariology education, like in Europe and other Latin American countries, theoretical activities in Brazil usually start in the second year of the course in dental education $[10,12]$. Preclinical exercises usually are scheduled during the second year, while clinical education usually starts in the third or fourth year, similar to the education structure in Europe [10].

With respect to differential diagnosis, in Brazil, $76.8 \%$ of the dental schools include dental erosion and $86.4 \%$ include defects of dental hard tissues in cariology education. The percentage of schools in Spanish-speaking Latin America that include erosion in cariology education was reported to be $64.8 \%$, lower than that observed in Brazil [12]. In Europe, more dental schools include this content in cariology education: $89.0 \%$ include dental erosion and $88.0 \%$ include defects of dental hard tissues [12]. Dental caries, erosion, and abrasion are processes that cause loss of dental hard tissue $[15,16]$. As a consequence, these items should be included in the cariology program in order to permit the student to perform a differential diagnostic. Concerning the content related to dental caries and dental erosion that is judged important for inclusion in a cariology curriculum (table 4), the present survey detected similar results when compared 
with investigations performed in other countries $[10,12]$.

The questionnaire also included a question related to supporting the development of a national curriculum of cariology. Regarding this, $84.8 \%$ of the respondents said that the dental school where they work would probably support it. This percentage was similar to Europe (89.0\%), where the survey about cariology education originated a consensus workshop that contributed to the European core curriculum in cariology [11]. These observations have encouraged the authors of this paper to propose that, in Brazil, a consensus workshop to create a Brazilian version of a cariology core curriculum should take place. The aim of providing such a curriculum is to guide dental schools about important matters related to cariology and therefore contribute to education quality.

To improve this quality, it is important that a national cariology curriculum approaches the prevention and promotion of oral health. In general, most of dentistry curricula is still structured in a technical-scientific emphasis, focused on curative practice, demonstrating a distance from teaching to the socioeconomic reality of the country [17]. This is worrying for a country where is evident a polarization of the prevalence of dental caries in socially vulnerable communities [18], and the opportunity of a workshop should be used to think cariology in a preventive view, being able to modifying this polarized panorama.

\section{CONCLUSION}

This survey was able to determine a panorama of the cariology education in Brazil, and the results indicated that the Brazilian scenario is similar to other countries where this initiative also took place. Therefore,

\section{REFERENCES}

1. Narvai PC, Frazão P, Roncalli AG, Antunes JLF. Dental Caries in Brazil: decline, polarization, inequality and social exclusion. Pan Am J Public Health. 2006;19(6):385-393. (Article in Portuguese)

2. Brasil. Ministério da Saúde. Projeto SBBrasil 2010: pesquisa nacional de saúde bucal - resultados principais. Brasília : Ministério da Saúde; 2011 [citado 2017 Out 10]. Disponível em: $\quad<$ http://189.28.128.100/dab/docs/geral/projeto_sb2010_ relatorio_final.pdf>

3. Sampaio FC, Rodrigues JA, Bonecker M, Groisman S. Reflection on the teaching of cariology in Brazil. Braz Oral Res. 2013;27(3):195- the promotion of a workshop to discuss the content that should be taught to dental students and to develop a Brazilian core curriculum in cariology would be likely to reduce the differences in teaching cariology in Brazil.

\section{Acknowledgements}

The authors declare no conflicts of interest. This research was carried out without funding. This research project has been supported by the board of directors of the Brazilian Association of Dental Education (ABENO) and the board of the Brazilian Chapter of the Alliance for Cavity Free Future (ACFF). The ABENO board of directors believes that the discussion of cariology curriculum directly applies in the discussion of the curriculum of dental education, since most of the disciplines are related to dental caries. The ACFF board highlights the importance of discussing the cariology curriculum in the country since new concepts in diagnosis, risk, and intervention have been developed in the last years, and they are very relevant to plan a cariesfree future for the population.

\section{Collaborators}

DB GOUVEA, data collection and analysis; critical revising for important intellectual content and agreement to be accountable for all aspects of the work in ensuring that questions related to the accuracy or integrity of any part of the work are appropriately investigated and resolved. S GROISMAN, MJS BÖNECKER, F SAMPAIO, SM PAIVA, L KRIGER, A SCHULTE and JA RODRIGUES contributions to the study design; data collection; critical revising for important intellectual content; agreement to be accountable for all aspects of the work in ensuring that questions related to the accuracy or integrity of any part of the work are appropriately investigated and resolved.

196. doi: $10.1590 / \$ 1806-83242013000300001$

4. Campos CMS, Soares CB, Trapé CA, Silva BRB, Silva TC. The relationship theory-practice and the teaching-learning process in a Collective Health Nursing Course. Rev Esc Enferm USP. 2009;43(2):1224-1229. doi: 10.1590/S008062342009000600014

5. European Society of Endodontology. Undergraduate Curriculum Guidelines for Endodontology. Int Endod J. 2001;34(8):574-580. doi: 10.1046/j.0143-2885.2001.00508.x

6. Hicklin SP, Albrektsson T, Hämmerle CHF. Theoretical knowledge in implant dentistry for undergraduate students. Eur J Dent Educ. 2009;13(1):25-35. doi: 10.1111/j.1600-0579.2008.00553.x 
7. Kossioni A, Vanobbergen J, Newton J, Müller F, Heath R. European college of Gerodontology: undergraduate curriculum guidelines in Gerodontology. Gerodontology. 2009;26(3):165-171. doi: 10.1111/j.1741-2358.2009.00296.x

8. European Academy of Pediatric Dentistry. A guideline framework for undergraduate education in Paediatric Dentistry. Eur Arch Paediatr Dent. 2009;10(2):114-119.

9. Sanz M, Meyle J. Scope, competences, learning outcomes and methods of periodontal education within the undergraduate dental curriculum: a Consensus report of the 1st European workshop on periodontal education - position paper 2 and consensus view 2. Eur J Dent Educ. 2010;14(1):25-33. doi: 10.1111/j.1600-0579.2010.00621.x

10. Schulte AG, Buchalla W, Huysmans MC, Amaechi BT, Sampaio $F$, Vougiouklakis $G$, et al. A survey on education in cariology for undergraduate dental students in Europe. Eur J Dent Educ. 2011;15(1)1:3-8. doi: 10.1111/j.1600-0579.2011.00708.x

11. Schulte AG, Pitts NB, Huysmans MC, Splieth C, Buchalla W. European core curriculum in cariology for undergraduate dental students. Caries Res. 2011;45(4):336-345. doi: $10.1159 / 000330006$

12. Martignon S, Gomez J, Tellez M, Ruiz JA, Marin LM, Rangel MC. Current cariology education in dental schools in Spanish-speaking Latin American countries. J Dental Educ. 2013;77(10):1330-1337.

13. Martignon S, Marín LM, Pitts N, Jácome-Liévano S. Consensus on domains, formation objectives and contents in cariology for undergraduate dental students in Colombia. Eur J Dent Educ.
2014;18(4):222-233. doi: 10.1111/eje.12091

14. Ferreira-Nóbilo NP, de Souza MLR, Cury, JA. Cariology in Curriculum of Brazilian Dental Schools. Braz Dent J. 2014;25(4):265-270. doi: 10.1590/0103-6440201300149

15. Ferreira-Nóbilo NP, de Souza MLR, Cury, JA. Conceptualization of dental caries by undergraduate students from the first to the last year. Braz Dent J. 2014;25(1):59-62. doi: 10.1590/01036440201302359

16. West NX, Joiner A. Enamel Mineral Loss. J Dent. 2014;42(1):2-11. doi: 10.1016/S0300-5712(14)50002-4

17. Pinheiro FMC, Nóbrega-Therrien SM, Almeida MEL, Almeida MI. A formação do cirurgião-dentista no Brasil: contribuições de estudos para a prática da profissão. RGO, Rev Gaúch Odontol. 2009;57(1):99-106

18. Narvai PC, Frazão P, Roncalli AG, Antunes JLF. Cárie dentária no Brasil: declínio, polarização, iniquidade e exclusão social. Rev Panam Salud Pública. 2006;19(6):385-393.

Received on: 30/10/2017

Final version resubmitted on: 23/2/2018

Approved on: 30/4/2018 